\title{
INOVASI PENDIDIKAN AKHLAQ BERBASIS MANAJEMEN QOLBU \\ di MI SUNAN KALIJOGO WOLUTENGAH KECAMATAN KEREK KABUPATEN TUBAN
}

\section{TAHUN PELAJARAN 2017/2018}

\author{
Ninik Hidayati, email : hidayatininik@gmail.com
}

Sadik

\begin{abstract}
The occurrence of acts and acts of violence lately is a phenomenon that we often witness. In fact it almost always adorns mass media information. One of the causes and perhaps this is the most important cause is due to a moral or moral crisis. Moral crisis occurs because some people no longer want to heed the guidance of religion, which normatively teaches adherents to do good, abandoning immoral acts and evil. The heart is a great gift that is given to humans. With a human heart can recognize, communicate, and even love Robnya. Like a tower, the heart has many doors. Like a mirror, the heart is able to absorb and reflect every image that comes to it. Then the influence, the object will enter the heart, and imprint in it, through the means of birth, namely the five senses or through the means of the mind, namely fantasy, lust, anger, morals formed in a fitrawi. Imagine if everyone then tried to base all their activities on a clean heart. Truly there will be a terrible explosion in changes in a person. The conclusion is that the qolbu managementbased moral education innovation is an idea or new method offered by the author to be used in implementing moral education. It is hoped that this new idea or method will be able to improve the quality of moral education which is felt to be declining today.
\end{abstract}

Keywords: Moral Education, Qolbu Management. 


\section{PENDAHULUAN}

Terjadinya aksi dan tindak kekerasan (violence) akhir-akhir ini merupakan fenomena yang seringkali kita saksikan.Bahkan hal itu hampir selalu menghiasi informasi media masa.Sebagaicontohadalah, terjadinya tawuran antarpelajar, pemerkosaan, pembakaran gedung, pembunuhan, pembantaian, dantindakanarkis yang lain. Itulah salah satu fenomena krisis akhlak yang kini tengah menimpa bangsa kita .Di samping itu, masih banyak krisis akhlak yang lain, seperti mabuk-mabukkan, penyalah gunaan narkotika, suap dan lain sebagainya .Krisis multi dimensional yang menimpa bangsa ini, salah satu penyebabnya-dan boleh jadi ini merupakan sebab yang paling utama- adalah karena terjadiny akrisis moral atauakhlak. Krisis moral terjadi karena sebagian besar orang tidak mau lagi mengindahkan tuntunan agama, yang secara normative mengajarkan kepad apemeluknya untuk berbua tbaik, meninggalkan perbuatan-perbuatan maksiat dan munkarat. 1

Islam memuj iakhlak yang baik, menyerukan kaum muslimin untuk membinanya, dan mengembangkannya di hati mereka .Islam menegaskan bahwa bukti keislaman ialah akhlak yang baik. Selain itu puncak derajat kemanusiaan seseorang dinila idari kualitas akhlaknya .Maka tak heran jika kualitas keimananpun di ukur dari akhlak. Seluas apapun kadar keilmuan seseorang tentang Islam, sehebat apapun dirinya ketika melakukan ibadah, atau sekencang apapun pengaduannya tentang kuatnyakeimanan yang dimilik isemua itu tidak bisa memberi jaminan. Tetapsaja, alatu kur yang paling akurat untuk menilai kemuliaan seseorang adalah kualita sakhlaknya.

Secara umum keduduk anakhlak adalah universal. Nilai-nilaistan dar tentang akhla ksudah di hujam kanoleh Allah Swt. Kedalam jiwa manusia sejak mereka lahir.Sebagaimana Firman Allah Swt:

$$
\text { فَالْهْهَهَا فُجُجْرَ هَاَ وَتَقْو اهَا (الشَمس: 8) }
$$

Artinya :Maka Allah mengilham 1 'epada jiw aitu (jalan) kefasikan dan ketaqwaannya (QS. Asy-Syams: 8).

\footnotetext{
${ }^{1}$ Gimnastiar, Abdulloh. 2002. Meraih Bening Hati Dengan Manajemen Qolbu, Jakarta: Gema Insani, perss
} 
Akhlak dalam Islam tidak semata didasarkan pertimbangan-pertimbangan kemanusiaan. Lebih dari itu akhla kadalah ibadah yang mesti di dasarkan atas semangat penghambaan kepada Allah Ta'ala .Seorang muslim menjadikan akhlaknya sebagai sarana mendekatkan diri pada Allah. Dia mengerjakan itu semuabukan didasarkan atas motivasi ingin mencari pamrih, pujian atau kebanggaan. Akhlak adalah rangkaian amal kebajikan yang diharapkan akan mencukupi untuk menjadi bekal kenegeri akhirat nanti. Namun demikian untuk memilik iakhlak yang mulia perlu adanya bimbingan secara khusus.

Salah satunya adalah melalui pendidikan akhlak .Hal inilah yang kemudian dijadikan alasan oleh penulis untuk memfokuskan pembahasan skripsi ini hanya pada pendidikan akhlak. Selanjutnya penulis juga akan membahas tentang qolbu (hati). Karena hati adalah anugerah agung yang Allah karuniakan pada manusia. Dengan hati manusia bisa mengenali, berkomunikasi, bahkan mencintai Rabnya, sekalipun mata dan telinga tiada sanggup meraih wujudnya. Hati adalah juga pusat kebahagiaan. Bahagia atau sengsara bukan tergantung pada seberapa sakinah kondisi hati yang ada dalam dada. ${ }^{2}$ Dan hati adalah aksi yang akan menyelamatkan atau mencelakakan. Orang yang kembali kepada Allah dengan hati yang bening berhak mendiami surga yang luasnya-seluas langit dan bumi. Sebagaimana Firman Allah SWT:

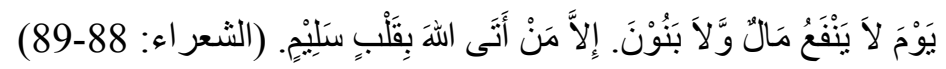

Artinya: (yaitu) di harihartadananak-anaklaki-lakitidakberguna. Kecuali orang-orang yang menghadap Allah denganhati yang bersih (QS. As-yua'raa': 88-89)

Laksana menara, hati memiliki banyak pintu. Ibarat cermin, hati mampu menyerap dan memantulkan setiap bayangan yang datang kepadanya. Maka pengaruh, obyek, akan masuk kedalam hati, dan membekas di dalamnya, melalui sarana lahir, yaitu panca indera, atau lewat sarana batin, yaitu khayalan, syahwat, amarah, akhlak yang terbentuk secarafitrawi.

Bayangkan kalau semua orang kemudian berusaha untuk mendasarkan seluruh aktivitasnya pada hati yang bersih, hati yang tidak ditanami oleh kedengkian, keprihatinan,

\footnotetext{
${ }^{2}$ Gimnastiar, Abdulloh. 2003. Refleksi Manajemen Qolbu, Bandung: MQ Plubising
} 
dan kesombongan. Sungguh akan terjadi ledakan dasyat pada perubahan diri seseorang. Sungguh akan terlihat perubahan yang benar-benar berarti serta penting dan perubahan sesaat. Allah Swt akan lebih memperkaya hati orang-orang sepertiini. Demikian juga dalam dunia pendidikan, alangkah lebih baiknya jika seluruh aktivitas pendidikan didasarkan pada hati yang bersih, khususnya untuk pendidikan akhlak. Karena dengan hati yang bersih akan mampu mencetak generasi muda yang berakhlak mulia, Insya Allah akan menjadi yang berbudi luhur

\section{KAJIAN TEORI}

\section{Pengertian Inovasi Pendidikan Akhlaq}

Perubahan dan inovasi keduanya sama dalam hal memiliki unsur yang baru atau lain dari sebelumnya. Tetapi inovasi berbeda dari perubahan, karena dalam inovasi dalam unsur kesengajaan.Pembaharuan misalnya dalam hal pembaharuan kebijaksanaan pendidikan mengandung unsur kesenngajaan dan pada umumnya istilah pembaharuan dapat disamakan dengan inovasi.

Secara etimologi inovasi berasal dari kata latininnovaation yang berarti pembaharuan dan perubahan.Kata kerjanya innovo yang artinya memperbarui dan mengubah. Inovasi ialah suatu perubahan baru yang menuju ke arah perbaikan dan berencana (tidak secara kebetulan saja). ${ }^{3}$

Inovasi Pendidikan Akhlaq adalah inovasi dalam bidang pendidikan atau inovasi untuk memecahkan masalah pendidikan Akhlaq. Jadi inovasi pendidikan Akhlaq adalah suatu ide, barang, metode yang dirasakan atau diamati sebagai hal yang baru bagi seseorang atau sekelompok orang (masyarakat), baik berupa hasil invensi (penemuan baru) atau discovery

\footnotetext{
${ }^{3}$ Hasbullah. 2001. Dasar-dasar Ilmu Pendidikan, Jakarta: PT Grafindo Persada
} 
(baru ditemukan orang), yang digunakan untuk mencapai tujuan pendidikan Akhlaq atau untuk memecahkan masalah yang dihadapi dalam pendidikan akhlaq.

Selanjutnya dijelaskan bahwa sesuatu yang baru itu, mungkin sudah lama dikenal pada konteks sosial atau sesuatu itu sudah lama dikenal, tetapi belum dilakukan perubahan. Dengan demikian, dapat disimpulkan bahwa inovasi adalah perubahan, tetapi tidak semua perubahan merupakan inovasi.

Selain tersebut diatas ada satu lagi definisi tentang inovasi Pendidikan ialah suatu perubahan yang baru dan kualitatif berbeda dari hal (yang ada) sebelumnya dan sengaja diusahakan untuk meningkatkan kemampuan guna mencapai tujuan tertentu dalam pendidikan. ${ }^{4}$

\section{KONSEP PENDIDIKAN AKHLAK}

\section{Pengertian Pendidikan Akhlak}

Pendidikan dapat diartikan sebagai bimbingan secara sadar oleh pendidik terhadap perkembangan jasmani dan rohani peserta didik menuju terbentuknya kepribadian yang utama. Oleh karena itu, pendidikan dipandang sebagai salah satu aspek yang memiliki peranan pokok dalam membentuk generasi muda agar memiliki kepribadian yang utama.

Kemudian di dalam Bahasa Arab, terdapat tiga istilah yang dipergunakan untuk menyebut kata pendidikan, antara lain; tarbiyat, tahzib, ta'lim, siyasat, mawa'izh, 'adat / ta'awwud, dan tadrib. Kata tarbiyat berasal, atau bahkan masdar dari akar kata Rabbun. Huruf " $r a "$ dan " $b a "$ menunjukkan kepada tiga makna dasar : Pertama, memperbaiki

\footnotetext{
${ }^{4}$ Muntahanah, Nurotun.2011 “Inovasi Pendidikan Akhlaq Berbasis Manajemen Qolbu” AL-Hikmah
} 
sesuatu dan berdiri diatasnya. Kedua, menekuni sesuatu dan menempati. Ketiga, menggabungkan sesuatu dengan sesuatu dengan sesuatu yang lain.

Makna ketiga (dari Ibnu Faris, meninggal tahun 393 H) mencakup semua pengertian tarbiyah baik secara umum atau khusus. Tarbiyah ialah membimbing seseorang dengan memperhatikan segala apa yang menjadi urusannya dan menggabungkan semua aspekaspek tarbiyah sampai ia matang dan mencapai batas kelayakan untuk dididik jiwanya, akhlaknya, akalnya, fisiknya, agamanya, rasa sosial politiknya, ekonominya, keindahannya, dan semangat jihadnya. Sedangkan menurut. Jika ditinjau dari tiga akar katanya, tarbiyah bisa dipahami dari tiga rangkaian berikut. Pertama, raba-yarbu yang maknanya bertambah dan berkembang. Kedua, raboya-yarba sebagaimana wazan khafiya-yakhfa, yang bermakna tumbuh dan berkembang. Ketiga, Raba-Yarubu sesuai wazan mada-yamudu, yang berarti memperbaiki, mengurusi, mengatur, menjaga dan memperhatikan. Selanjutnya kata ta'lim diartikan pengajaran dan siyasat bisa diartikan siasat, pemerintahan, politik, atau pengaturan. 'Adat / ta'awwud diartikan pembiasaan, dan tadrib bisa diartikan pelatihan.

Menurut Hasan Langgulang yang dimaksud dengan pendidikan adalah suatu proses yang mempunyai tujuan yang biasanya diusahakan untuk menciptakan pola-pola tingkah laku tertentu pada anak-anak atau orang yang sedang dididik. Sedangkan menurut John Dewey pendidikan adalah sebagai suatu proses pembentukan kemampuan dasar yang fundamental, baik mengangkut daya pikir (intelektual) maupun daya perasaan (emosional) menuju kearah tabiat manusia dan manusia biasa. ${ }^{5}$

\footnotetext{
${ }^{5}$ Hasbullah. 2001. Dasar-dasar Ilmu Pendidikan, Jakarta: PT Grafindo Persada
} 


\section{Definisi Manajemen Qolbu}

Sebelum berbicara lebih jauh tentang Manajemen Qolbu, maka terlebih dahulu akan penulis paparkan definisi Manajemen Qolbu itu sendiri. Manajemen Qolbu terdiri dari dua kata, yaitu Manajemen dan Qolbu. Manajemen adalah suatu hal penting yang menyentuh, mempengaruhi dan bahkan merasuki hampir seluruh aspek kehidupan manusia layaknya darah dalam raga. Juga telah dimengerti bahwa dengan manajemen, manusia mampu mengenali kemampuannya berikut kelebihan dan kekurangannya sendiri.Manajemen menunjukkan cara-cara yang lebih efektif dan efisien dalam pelaksanaan suatu pekerjaan. Manajemen telah memungkinkan kita untuk mengurangi hambatan-hambatan dalam rangka pencapaian suatu tujuan.Manajemen juga memberikan prediksi dan imajinasi agar dapat mengantisipasi perubahan lingkungan yang serba cepat.

Sedangkan di dalam Al-Qur'an telah diberikan stimulasi mengenai manajemen, sebagaimana dalam Firman-Nya.

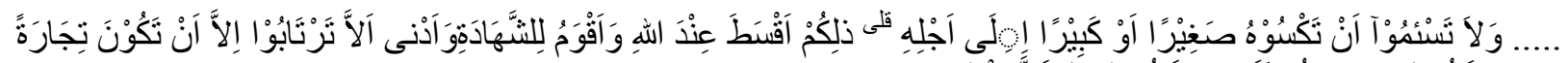

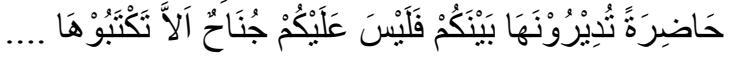

“...... Dan janganlah kamu jemu menulis hutang itu, baik kecil maupun besar sampai batas

waktu membayarnya. Yang demikian itu lebih adil di sisi Alloh dan lebih dapat menguatkan persaksiat dan lebih dekat kepada tidak (menimbulkan) keraguanmu, (tulislah muamalahmu itu) kecuali jika muamalah itu perdagangan tunai yang kamu jalankan diantara kamu, maka tidak ada dosa bagi kamu (jika) kamu tidak menulisnya .....”(Al Baqoroh : 282)

Dalam ayat tersebut, disebutkan arti sebagai berikut :Pertama, Idaaroh adalah keadaan timbal balik, berusaha supaya menetapi peraturan yang ada. Kedua, Idarah atau

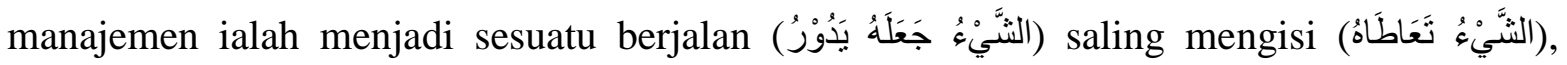
persoalan atau pendapat (الأُعْرْ وَالرَّأَبُ ). Menurut Jawahir yang mengutip buku Rooidut Tullab 
bahwa Idaroh adalah perkumpulan Syarikat Madrasah, Yayasan, Sarana atau perlengkapan untuk menyelesaikan segala urusan untuk mencapai hasil atau meningkatkan produktivitas. Adapun koordinator Dakwah Islam DKI merumuskan pengertian Idarah adalah perencanaan dan pengendalian segala sesuatu secara tepat guna.

Disamping ayat Al Qur'an, Hadits Nabi SAW juga telah memberikan gambaran tentang manajemen

1. Planning (niat), sebagai formulasi tindakan dimasa mendatang, diarahkan kepada tujuan yang akan dicapai oleh organisasi. Niat merupakan padanan planning yang bersikap intrinsik dan manusiawi.

2. Organizing adalah upaya mempertimbangkan suasana organisasi, pembagian pekerjaan, prosedur pelaksanaan, pembagian tanggung jawab dan lain-lain.

Hadits Nabi SAW : "Hendaklah kamu berada dalam jama'ah, karena sesungguhnya jama’ah itu rahmat, sedangkan perpecahan itu adab. "

3. Comunicating, Hadits Nabi SAW menjelaskan bahwa dalam proses komunikasi harus memperhatikan kemampuan atau berorientasi pada khalayak, sehingga feed back-nya sesuai dengan harapan :"Bicaralah kamu sekalian sesuai dengan kadar akal / pikiran manusia."

4. Controlling. Dalam hadits dinyatakan : "Tidak ada seorang hamba yang siberi kepercayaan oleh Allah untuk memimpin lalu ia tidak memelihara dengan baik, melainkan Allah tidak akan merasakan kepadanya bau surga.”

5. Motivating; yaitu memberikan dorongan semangat untuk mencapai tujuan bersama. Hadits Nabi SAW : "Kasihanilah mereka yang ada di bumi niscaya yang dilangit akan mengasihi kamu." 
6. Actuating; Pola pekerjaan teradu. Dalam shahih Muslim disebutkan :"Tolong-menolong sesama muslim seperti sebuah bangunan yang kukuh teguh karena saling sokong menyokong.

Dari definisi di atas, dapat diambil kesimpulan bahwa manajemen (Idaarah) ialah suatu proses dari kegiatan usaha yang terdiri dari planning, organizing, communicating, controlling, staffing, motivating, actuating yang diterapkan individu atau kelompok dalam upaya-upaya koordinasi untuk mencapai suatu tujuan.

Adapun kata Qolbu memiliki dua makna. Pertama, secara anatomi Qolbu adalah sepotong daging yang bentuknya menyerupai tumbuhan sanaubar yang teletak di bagian kiri dada, di dalamnya terdapat rongga berisi darah hitam. Kedua, Qolbu adalah sebuah latifah (Sesuatu yang amat halus dan lembut, tidak kasat dan tidak dapat diraba) yang bersifat Robbani Ruhani. Latifah tersebut sesungguhnya adalah jati diri atau hakekat manusia. Searah dengan makna yang kedua ini, banyak ahli tassawuf yang mendefinisikan kata Qolbu sehingga penulis tidak bisa menyebutkan satu persatu definisinya. Namun yang perlu difahami bahwa hati (Qalbu) tersebut adalah bagian (komponen) utama manusia yang berpotensi menyerap (memiliki daya tanggap atau persepsi) yang dapat mengetahui dan mengenal, yang ditujukan kepadanya segala pembicaraan, penilaian, kecaman dan pertanggung jawaban. ${ }^{6}$

Qolbu adalah dari hati nurani atau lubuk hati paling dalam, yang merupakan sarana terpenting yang telah dikaruniakan Allah kepada manusia. Hati adalah tempat bersemayam niat, yakni yang menentukan nilai perbuatan seseorang : Berharga ataukah sia-sia, mulia atau nista.

\footnotetext{
${ }^{6}$ Gimnastiar, Abdulloh. 2003. Refleksi Manajemen Qolbu, Bandung: MQ Plubising
} 
Niat ini selanjutnya diproses oleh akal pikiran agar bisa direalisasikan dengan efekif dan efisien oleh jasad kita dalam bentuk amal perbuatan. ${ }^{7}$

Hati juga disebut sebagai sesuatu yang ada di dalam tubuh manusia yang dianggap sebagai tempat (pusat) segala perasaan batin dan tempat menyimpan menyimpan pengertianpengertian (perasaan-perasaan, dsb). Arti lainnya, hati merupakan pusat pemahaman / internalisasi. Pusat Instutional Intelectual (II). Pusat memori dari semua amal (baik buruk).Indera perasaan (rasa halus) untuk penerapan hal yang abstrak. Indera hati (mata dan telinga hati), untuk pencerapan alam ghaib. ${ }^{8}$

\section{Hubungan Akhlak Dengan Manajemen Qolbu}

Akhlak merupakan pondasi yang kokoh bagi terciptanya hubungan baik antara hamba dan Allah SWT (Hablumminallah) dan antar sesama (Hablumminannas). Akhlak yang mulia tidak lahir berdasarkan keturunan atau terjadi secara tiba-tiba, akan tetapi, membutuhkan proses panjang. Yakni melalui pendidikan akhlak.Banyak sistem pendidikan akhlak, moral atau etika yang ditawarkan oleh Barat, namun banyak juga kelemahan dan kekurangannya.Karena memang berasal dari manusia yang ilmu dan pengetahuannya sangat terbatas.

Sementara pendidikan akhlak yang mulia yang ditawarkan oleh Islam tentunya tidak ada kekurangan apalagi kerancuan di dalamnya.Mengapa ?Karena berasal langsung dari Al Khalik Allah SWT, yang disampaikan melalui Rasulullah Muhammad SAW, dengan Al Qur'an dan Sunnah kepada umatnya.Rasulullah SAW sebagai Uswah, Qudwah dan manusia terbaik selalu mendapatkan tarbiyah "Pendidikan" langsung dari Allah melalui Malaikat 
Jibril. Sehingga beliau mampu dan berhasil mencetak para sahabat menjadi sosok-sosok manusia yang memiliki Izzah di hadapan umat lain dan akhlak mulia di hadapan Allah.

Manajemen Qalbu merupakan suatu upaya yang terus menerus untuk melatih menata hati (Qalbu) sehingga Qalbu itu memiliki sifat yang hanif (lurus), dan tentu saja menjadikan niat ibadah sebagai landasan dalam melakukan perbuatan apapun. Manusia bukanlah roh saja, atau bukan juga sepotong jasmani.Keduanya adalah satu dalam satu manusia. Apakah yang akan jadi akibat jika kita mempunyai satu pikiran dalam hati kita? Pikiran itu tentu akan mempunyai pengaruh pada jasmani manusia. Karena manusia tahu bahwa ia berbuat salah, dan berbuat salah itu berupa sebagai beban dalam hatinya, dengan sendirinya pengertian kesalahan itu akan mempunyai akibat dalam rasa perasaan manusia. Ia bersalah, salah mempunyai sanksi (tuntutan pembalasan), dari itu timbul rasa takut dalam diri manusia. Rasa takut karena tiap kesalahan batin pada hakikatnya akan mengingatkan kita kepada pencipta hukum alam yang tertanam dalam hati sanubari manusia, dari itu manusia merasa takut karena telah berbuat yang bertentangan dengan kehendak pembuat hukum kodrat manusia.

Dari uraian di atas dapat disimpulkan bahwa sesungguhnya akhlak bergantung pada Qalbu.Qalbu yang baik melahirkan akhlak yang baik, Qalbu yang buruk melahirkan akhlak yang buruk.Artinya Qalbu merupakan kunci dari akhlak seseorang dan akhlak ini yang menetukan kemampuan seseorang untuk menyelesaikan setiap masalah yang datang.Qalbu yang hanif (lurus, baik) tidak mungkin tercipta tanpa iman, ilmu dan latihan.Salah satunya adalah dengan Manajemen Qalbu. ${ }^{9}$

\footnotetext{
${ }^{9}$ Gimnastiar, Abdulloh. 2002. Meraih Bening Hati Dengan Manajemen Qolbu, Jakarta: Gema Insani, perss
} 


\section{METODE PENELITIAN}

Dalam penelitian ini digunakan pendekatan kualitatif, yang memiliki karakteristik alamiah (natural setting) sebagai sumber data langsung, deskriptif, proses lebih diutamakan dari pada hasil, analisis dalam penelitian kualitatif cenderung dilakukan secara induktif dan makna merupakan hal yang esensial. ${ }^{10}$

\section{PEMBAHASAN}

\section{Analisis Tentang Pelaksanaan Manajemen Qalbu di MI Sunan KalijogoWolutengah}

Hati adalah amanah yang harus dijaga dengan penuh kesungguhan. Seseorang tidak dapat mengatur dan menata hati, kecuali dengan memohon pertolongan Allah SWT agar selalu menjaga hati setiap orang. Hati adalah pangkal kehidupan, jika Allah SWT memberikan seseorang hati yang bening, maka ia akan mendapatkan banyak keuntungan dan dapat mencapai sesuatu sesuai dengan keinginan. Semua ini kuncinya adalah dengan menjaga hati, akan tetapi harus diingat bahwa Allah SWT maha kuasa, dapat dengan mudah membolak-balikkan hati seseorang, dari bersih menjadi kotor lagi. Oleh karenanyalah penting untuk melakukan manajemen qalbu atau pengelolaan terhadap hati agar senantiasa terjaga dengan baik

Sebagaimana MI Sunan Kalijogo Wolutengah begitu memahami akan pentingnya menjaga dan mengelola hati agar senantiasa baik. Yang mana pihak Madrasah berpendapat bahwa hati manusia adalah kunci kebaikan seseorang, mengibaratkan hati layaknya raja yang memiliki peran penting dalam sebuah tatanan negara. Mengibaratkan hati layaknya tanah, jika tanah dibiarkan begitusaja tanpa dirawat pasti akan ditumbuhi oleh tumbuhan liar, semak belukar dan semacamnya. Ini menggambarkan pandangan MI Sunan Kalijogo

\footnotetext{
${ }^{10}$ Bungin, Burhan. 2008. Metodologi Penelitian Kualitatif, Jakarta: PT Raja Grafindo Persada
} 
akan betapa penting hati manusia harus ditata dan dikelola terutama bagi para siswa yang masih dalam proses menuntut ilmu yang haus akan bimbingan dan pembinaan agar menjadi manusia yang baik. Ini selaras dengan pendapat imam al-Ghazali yang menyatakan bahwa "'hati adalah raja ${ }^{\text {eeee }}$. Adapun upaya yang dilakukan pihak Madrasah dalam menerapkan pengelolaan hati kepada siswa adalah:

1. Perencanaan.

Terlebih dahulu pihak MI Sunan Kalijogo melakukan musyawarah sebelum melaksanakan rangkaian kegiatan tersebut. Yaitu dengan merancang program pengelolaan hati bagi siswa agar selaras dengan tujuan Madrasah untuk membawa dan mengarahkan seluruh siswanya supaya menjadi siswa yang baik, mandiri dan mulia atau lebih lengkapnya adalah, menjadi manusia seutuhnya yaitu insan kamil yang mencerminkan tujuan pendidikan Indonesia sebagaimana termuat dalam UndangUndang Nomor 20 Tahun 2003 tentang Sistem Pendidikan Nasional Bab II Pasal 3. Yang secara ringkas adalah, bertujuan untuk melahirkan generasi yang paripurna.

2. Pelaksanaan manajemen qalbu.

MI Sunan KalijogoWolutengah menyelenggarakannya melalui dua kegiatan pokok. Pertama adalah upaya untuk melatih siswa agar senantiasa mampu memebersihkan diri. YaituUndang-Undang Nomor 20 Tahun 2003 tentang Sistem Pendidikan Nasional Bab II Pasal 3.membersihkan diri dari keburukan-keburukan termasuk membersihkan diri dari sifat-sifat tercela. Dan ini merupakan perkara yang sangat penting, sebagaimana pendapat Moh. Faizin bahwa kesuksesan dalam konsep manajemen qolbu adalah pembersihan hati yang dilakukan secara istiqomah di sepanjang kehidupan. Di sisi lain kebersihan hati merupakan kunci keberhasilan untuk bisa bertemu dengan Allah SWT. 
Dengan demikian puncak kesuksesan bermuara pada kebersihan hati." Adapun langkah yang ditempuh Madrasah untuk melatih siswa agar mampu membersihkan diri adalah dengan (a) sholat malam, (b) dzikir, dan (c) tilawah al-Qur"an. Dan Ini sesuai dengan yang disampaikan oleh Yon Noviar dalam bukunya Qalbu Quotien mengenai upaya untuk membersihkan hati.

Kedua melatih siswa agar mampu menjaga potensi diri dengan amal sholeh dan akhlaq mulia. Setelah diri dibersihkan dari keburukan-keburukan yang melekat padanya, selanjudnya dilakukan usaha untuk menghiasi diri dengan akhlaq mulia dengan cara; (a) Mempelajari tertib ibadah sehari-hari dan keutamaan amal, ini diterapkan untuk meningkatkan semangat para siswa dalam menjalankan kebaikan. (b) Mempelajari akhlaq mulia yang dicontohkan shabat Rasulullah SAW (c) Menerapkan perilaku mulia melalui adab perilaku shari-hari. (d) Latihan untuk memuliakan sesama muslim dengan silaturrahmi.

Nastiar dalam bukunya Memperbaiki Diri Lewat Manajemen Qalbu yang mejelaskan bahwa, setidaknya ada dua kunci utama untuk menyelengarakan Manajemen Qalbu. Dua kunci tersebut adalah; pertama, dimulai dengan membiasakan diri untuk senantiasa melakukan pembersihan diri atau hati, dan yang kedua hendaknya senantiasa berusaha untuk meningkatkan kualitas atau profesionalitas diri dalam hal apapun.

3. Berikutnya adalah pengawasan kegiatan.

Hal ini dilakukan oleh Madrasah secara berkesinambungan ketika pelaksanaan dan setelah pelaksanaan, ini berfungsi untuk mengidentifikasi kekurangan-kekurangan dalam pelaksanaan yang kemudian perlu diadakanya penyempurnaan pelaksanaan. 
Ketiga point diatas menunjukkan bahwa penerapan manajemen qalbu di MI Sunan KalijogoWolutengah telah memenuhi tiga unsur dari empat fungsi manajemen yang dikemukakan oleh Gorge Terry sebagaimana yang telah dikutip oleh Irenius dan Ratna, yaitu planning (perencanaan), actuating (pelaksanaan), controlling (pengawasan).133Dan yang menjadi keunikan tersendiri dari pelaksanaan manajemen qalbu di MI Sunan KalijogoWolutengah adalah menerapkan konsep tersebut melalui pendekatan khuruj. Yaitu sebuah kegiatan yang telah diselengarakan Madrasah yang diadopsi dari Jamaah Tabligh. Meski demikianAbdullah Gymnastiar, Memperbaiki Diri Lewat Manajemen Qalbu. Faktor Determinan Rendahnya Pencapaian Cakupan Standar Pelayanan Minimal Bidang Kesehatan di Puskesmas Surabaya ${ }^{\text {eeee }}$, Administrasi Kesehatan Indonesia.

Secara umum penerapan manajemen qalbu di MI Sunan KalijogoWolutengah sebagaimana penjelasan diatas, telah dilaksanakan dengan baik.

Demikianlah analisis tentang pelaksanaan manajemen qalbu yang diselenggarakan MI Sunan Kalijogo Wolutengah. Bahwa usaha manajemen qalbu dalam hal ini pengelolaan hati sudah sesuai dengan konsep teori. Pertama, perencanaan kegiatan manajemen qalbu diselenggarakan secara musyawarah, menyesuaikan rancangan kegiatan dengan tujuan Madrasah yaitu untuk mencetak generasi yang paripurna. Kedua pelaksanaan manajemen qalbu diselenggarakan melalui kegiatan praktis melalui pendekatan khuruj fii sabilillah yang didalamnya memuat seni menata hati yang meliputi; (a) Usaha atau latihan membersihkan hati yaitu, qiyyamul lail, dzikir, tilawah al-Qurean (b) Menjaga potensi diri dengan amal sholeh dan akhlaq mulia dengan cara, mempelajari tertib ibadah sehari-hari dan keutamaan amal, mempelajari akhlaq 
mulia yang dicontohkan Rasulullah SAW dan sahabat, menerapkan perilaku mulia melalui adab perilaku shari-hari, latihan untuk memuliakan sesama muslim dengan silaturrahmi. Ketiga pengawasan pelaksanaan manajemen qalbu dilakukan secara berkesinambungan ketika pelaksanaan dan setelah pelaksanaan.

\section{Analisis Faktor Pendukung Dan Penghambat Pelaksanaan Manajemen Qalbu di MI}

\section{Sunan Kalijogo Wolutengah}

\section{Faktor Pendukung}

Upaya untuk mewujudkan penerapan manajemen qalbu di MI Sunan Kalijogo memiliki banyak hal yang mendukung. Faktor pendukung sendiri adalah hal-hal yang dapat membantu terjadinya proses penerapan manajemen qalbu atau pembinaan hati di MI Sunan Kalijogo. Diantaranya faktor-faktor yang mendukung itu adalahLingkungan Madrasah yang kondusif agamis.

Bagaimanapun juga lingkungan dimana seseorang tinggal entah itu baik ataupun buruk pasti akan berpengaruh kepada orang tersebut sebagai anggota yang hidup didalamnya. Dengan adanya lingkungan Madrasah yang kondusif dan sangat kental dengan nilai-nilai agama pasti akan sangat memudahkan para siswa untuk menjaga kondisi hatinya agar senantiasa baik dan terhindar dari pengaruh-pengaruh buruk yang biasanya berasal dari lingkungan tempat tinggal.

\section{Faktor Penghambat}

Berbagai upaya telah dilakukan MI Sunan Kalijogo untuk membekali para siswanya dalam meningkatkan aspek kecerdasan spiritual dengan melakukan penyelenggarakan rangkaian pembinaan hati kepada para siswanya. Namun dalam hal itu MI Sunan Kalijogo masih menemui beberapa kendala yang menghambat keberhasilan dari proses manajemen 
qalbu itu sendiri. Faktor-faktor penghambat itu datang dari dalam diri siswa dan juga dari luar diri siswa yaitu lingkungan keluarga siswa sendiri.

Sebagaimana halnya seorang anak, para siswa juga memiliki psikologi yang sama. Sifat siswa yang sebagian ada yang belum dewasa sering berubah-ubah dan ketika siswa itu merasa senang maka hal itu akan menjadi faktor pendukung namun ketika anak tidak senang maka itu akan menjadi kendala terlaksananya kegiatan pembinaan hati. Manajemen qalbu adalah masalah batiniah, jadi ketika seorang siswa belum paham masalah itu maka akan sulit untuk di lakukan internalisasi nilai-nilai manajemen qalbu.

Faktor penghambat selanjutnya muncul ketika siswa terlalu lama meninggalkan lingkungan Madrasah. Ketika siswa lama meninggalkan Madrasah maka lama kelamaan siswa juga akan melupakan kebiasaannya di Madrasah, dan kembali mengikuti kebiasaan di lingkungan dia tinggal. Hal semacam ini banyak terjadi pada siswa-siswa baru, mereka baru nyantri sehingga tradisi yang ada di Madrasah belum menjadi karakter bagi dirinya. Namun ketika tradisi itu sudah menjadi karakter maka akan terus melekat pada diri siswa, dimanapun siswa itu tinggal.

Dengan demikian bisa dikatakan bahwa, faktor-faktor yang mendukung proses pengpenerapanan manajemen qalbu atau pembinaan hati di MI Sunan Kalijogo ini meliputi (a) adanya tharekat Naqsabandiyah Qholidiyah yang muktabarah, (b) Madrasah dijadikan sebagai pusat jamaeah Tabligh, (c) Lingkungan Madrasah yang kondusif agamis. Sedangkan faktor-faktor penghambat proses penerapan manajemen qalbu di MI Sunan Kalijogo meliputi; (a) psikologi siswa yang sebagian masih belum stabil. (b) Lingkungan masyarakat atau keluarga siswa sebagian kurangkondusif. Dan langkah yang ditempuh Madrasah dalam menyikapi persoalan diatas adalah dengan memberikan kesempatan kepada siswa untuk 
berkonsultasi kepada guru terutama guru pembimbing. Serta pihak Madrasah berusaha menjalin komunikasi dengan para wali siswa agar selalu memiliki tujuan yang sama dalam mendidik anak.

\section{KESIMPULAN DAN SARAN}

\section{KESIMPULAN}

Berdasarkan penelitian di atas tentang Inovasi Pendidikan Akhlaq Berbasis Manajemen Qolbu di MI Sunan Kalijogo Desa Wolutengah Kerek Kerek Kabupaten Tuban Tahun 2017/2018 dapat di simpulkan bahwa:

1 Cara melakukan inovasi pendidikan akhlak berbasis manajemen qolbu adalah senantiasa menghiasi diri dari sifat-sifat terpuji, sesudah membersihkannya dari sifat-sifat tercela, menghapus kecintaan terhadap dunia serta menghilangkan segenap kesedihan, kedukaan dan kekhawatiran atas segala sesuatu yang tidak berguna dengan cara senantiasa dan terus menerus mengingat Allah (Dzikrullah), kemudian adanya tekad yang kuat, mau mengevaluasi diri dan senantiasa berkemauan kuat untuk meningkatkan kemampuan (keprofesionalan) diri dalam bidang apapun.

2 Hasil inovasi pendidikan akhlak berbasis manajemen qolbu adalah untuk membentuk karakter anak yang disiplin, berbudi luhur, sopan santun, dan rendah hati. Dan mampu membedakan mana yang halal dan mana yang haram serta mengaplikasikan dalam lingkungan keluarga.

Sedangkan bentuk pelaksanaan manajemen qolbu yang bersifat kelompok, dilaksanakan dengan sistem ta'lim yang dibagi kedalam beberapa kelompok lain. Materi yang diberikan bertendensi kepada pembentukan akhlak seperti: kesabaran, kejujuran, keteladanan. Dan ada tiga materi pokok yang terkait dengan manajemen qolbu yaitu keutamaan hati, mengenal potensi manusia dan potensi dir $\quad{ }_{96}^{*}$ ' ;erta pengenalan diri. 
Dari hasil wawancara peneliti dengan siswa kelas V dapat diketahui bahwa anak anak yang masih belum tahu bahwasanya pendidikan akhlak itu penting sebanyak $10 \%$ sedangkan yang merasa penting adalah 90\%. Maka dari hasil yang diperoleh peneliti dapat disimpulkan bahwa dengan dilaksanakanya kegiatan pendidikan akhlak itu penting untuk membentuk karakter anak sehingga Kegiatan pendidikan akhlak telah tertanam dalam diri anak, terbukti $65 \%$ anak - anak menerapkannya di rumah.

\section{SARAN}

1. Kepada para pendidik

Kepada para Pendidik hendaknya dapat memilih metode pengajaran pendidikan akhlak yang sesuai dengan kebutuhan peserta didik. Sehingga dapat meningkatkan mutu pendidikan akhlak yang dirasakan makin menurun dewasa ini. Dan dengan sistem yang tepat diharapkan peserta didik dapat menjadi manusia yang benar-benar berakhlak mulia.

2. Kepada para orang tua

Kepada para orang tua hendaknya memberikan contoh yang baik kepada anakanak mereka. karena orang-orang yang ada disekitar mereka akan dijadikan acuan untuk diidolakan (dijadikan teladan). Selain itu hendaknya orang tua menanamkan pendidikan akhlak sejak dini kepada anak-anak mereka agar ketika dewasa nanti mereka sudah terbiasa dengan tingkah laku yang positif.

\section{Kepada para pembaca}

Kepada para pembaca yang lain hendaknya senantiasa berusaha untuk memperbaiki diri. Karena sesungguhnya akhlak merupakan urusan manusia sendiri. Artinya baik buruk, terpuji atau tercelanya akhlak seseorang adalah tergantung kepada orang itu. 


\section{REFERENSI}

Departemen Agama RI, Al qur an dan Terjemah, Bandung CV Penerbit Jumatul Al-Art J-ART. 2004

Gimnastiar, Abdulloh, Meraih Bening Hati Dengan Manajemen Qolbu, Jakarta: Gema Insani, perss, 2002

Imam Al-ghajali, Benang Tipis antara Haelal dan Haram,Putra pelajar, 2002

Margono, 1997,Metodologi penelitian pendidikan, Jakarta, PT Rineka cipta

ER,Umar 2011 Panduan Sholat dan do'a Surabaya: Lingkar media

Gimnastiar, Abdulloh, 2003, Refleksi ManajemenQolbu, Bandung: MQ Plubising

Sangkan; Abu,Berguru Kepada Allah, Jakarta:Yayasan Sholat Khusu’ 2006. 